\title{
Congenital Infiltrating Lipomatosis of the Face Case Report and Literature Review
}

\author{
Yatong Li, MD, * Guojing Chang, MD, * Loubin Si, MD, * Hailin Zhang, MD, * Xiaoyan Chang, MD, $†$ \\ Zhixiong Chen, MD, * Jiuzuo Huang, MD, * Ming Bai, MD, * Yang Wang, MD, * \\ Xiao Long, $M D,{ }^{*}$ Ru Zhao, MD, * and Xiaojun Wang, MD*
}

\begin{abstract}
Rationale: Congenital infiltrating lipomatosis of the face (CILF) is a rare disorder characterized by collections of nonencapsulated mature lipocytes that infiltrate surrounding tissues. In this article, we would report a new case of CILF, which may be one of the first few cases reported in China.

Patient Concerns: An 8-year-old boy presented with a hyperplasia of subcutaneous tissue of his left face, which had been gradually progressing since birth, resulting in a marked facial asymmetry. Then he underwent an operation of resection of the subcutaneous mass, and the postoperative pathological analysis reported a mature adipose tissue.

Diagnoses and Outcomes: The diagnosis of CILF was finally made according to a comprehensive consideration of the patient's situation. We then searched different databases for studies that had investigated CILF, reviewed those literatures, and gave our summaries for such a rare disease.

Lessons: Congenital infiltrating lipomatosis of the face is an extremely rare disease. There is so much unknown about it, and the gradual progress and recurrence make it even harder to cure. Besides, the psychological impact on such patients must be considered. Thus, a proper collection and analysis of the reports of such a disease are very important.
\end{abstract}

Key Words: congenital infiltrating lipomatosis of the face, hyperplasia of facial subcutaneous tissue, gradual progress, macrodontism

(Ann Plast Surg 2018;80: 83-89)

ongenital infiltrating lipomatosis of the face (CILF) is a very rare disorder in which mature lipocytes invade into adjacent tissues in the facial region. ${ }^{1-4}$ The manifestation is always unilateral, with hypertrophy of both soft and hard structures on the affected side of the face. Congenital infiltrating lipomatosis of the face is a nonhereditary disease. The gradual enlargement of the affected side of the face and the resulting facial asymmetry are crucial features (100\%). Besides, macrodontism, early eruption of deciduous and permanent teeth, hypertrophy of bones, macroglossia, and the proliferation of parotid gland on the affected side are all possible results. ${ }^{1-4}$ In our study, we would like to report a new case of CILF, which is one of the first few cases reported

Received May 1, 2017, and accepted for publication, after revision July 20, 2017. From the *Departments of Plastic Surgery, and $\uparrow$ Pathology, Peking Union Medical College Hospital, Beijing, China.

Yatong $\mathrm{Li}$ and Guojing Chang are co-first authors.

Conflicts of interest and source of funding: none decalred.

Reprints: Xiaojun Wang, MD, Department of Plastic Surgery, Peking Union Medical College Hospital, Beijing, China, 100730. E-mail: pumchwxj@163.com.

Copyright (C) 2017 The Author(s). Published by Wolters Kluwer Health, Inc. This is an open-access article distributed under the terms of the Creative Commons Attribution-Non Commercial-No Derivatives License 4.0 (CCBY-NC-ND), where it is permissible to download and share the work provided it is properly cited. The work cannot be changed in any way or used commercially without permission from the journal.

ISSN: 0148-7043/18/8001-0083

DOI: $10.1097 /$ SAP.0000000000001213 in China. Because CILF is very rare, we hope that our report and review of literatures will give more suggestions for the diagnosis and treatment of this disease.

\section{CASE REPORT}

An 8-year-old boy was admitted to our hospital in December 2016, having suffered from a hyperplasia of subcutaneous tissue of his left face since birth. At that time, the upper boundary of the left cheek enlargement was his left arcus zygomaticus, the lower boundary was his left mandibula, the inner boundary was the left side of his nose and mouth, and the outer boundary was the vertical line of the outer corner of his left eye (Fig. 1A). He came from a full-term pregnancy of nonconsanguineous parents. The prenatal history was normal, and his mother denied any press or injury during the stage of labor, and there were no asphyxia, pathological jaundice, or other neonatal diseases. Developmental milestones were normal. The swelling gradually progressed in size, resulting in an asymmetry of the face, and there were no any diagnosis or treatment. When he presented to us, the 4 boundaries of the mass were almost the same as born, except for the inner boundary, which progressed to the midline of the boy's nose and mouth (Fig. 1B). During the whole course of the disease, the patient denied any discomforts, including fever, pain, hypoesthesia, weakened muscular strength, obnubilation, or unconsciousness. Moreover, there was no early eruption of deciduous or permanent teeth on the left side.

The past, personal, and family history of the patient were all clear. The physical examination showed an enlargement of the left face, measured approximately $10 \times 7 \mathrm{~cm}$. The midline of the face moved right, whereas the left nasolabial fold was lighter, and the left palpebral fissure was smaller than that of right (Fig. 1C). However, there was nothing special of the left facial mass compared with the right face. The color and texture of the skin were normal, and the pain was negative. The cranial nerves examination also presented no positive results. The sense, muscular strength, and muscular movement of the left face were all as normal as that of right.

The blood examination of this patient showed nothing special, as well as the ultrasound and electromyography test results. The 3-dimension computed tomography (CT) examination reported a symmetrical skull without any malformation or asymmetry externally. However, an abnormal big left upper canine could be seen, which led to an absence of the left upper lateral incisor, and a dislocation of the left upper incisor (Fig. 2A). The teeth CT examination also reported those relatively bigger left teeth, which conformed the performance of macrodontism (Fig. 2B). Besides, bone asymmetry of maxillary alveolar ridge was also shown (Fig. 2B). The magnetic resonance imaging (MRI) examination reported a hyperplasia of the subcutaneous tissue of the left face. According to the density and characters of the mass, we guessed it as subcutaneous lipomatosis 


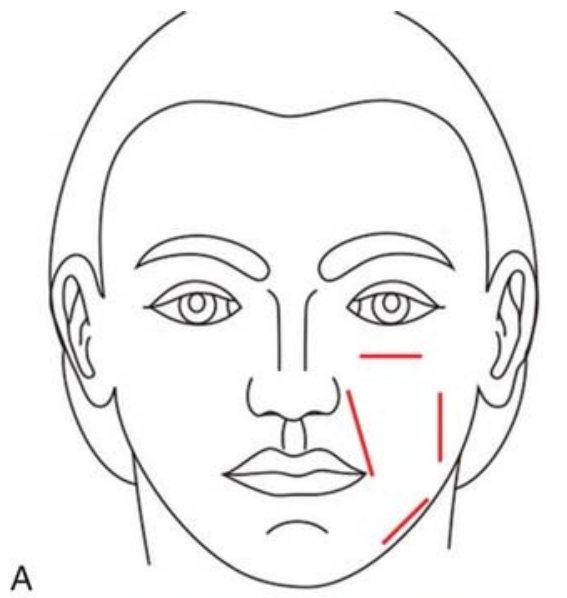

B
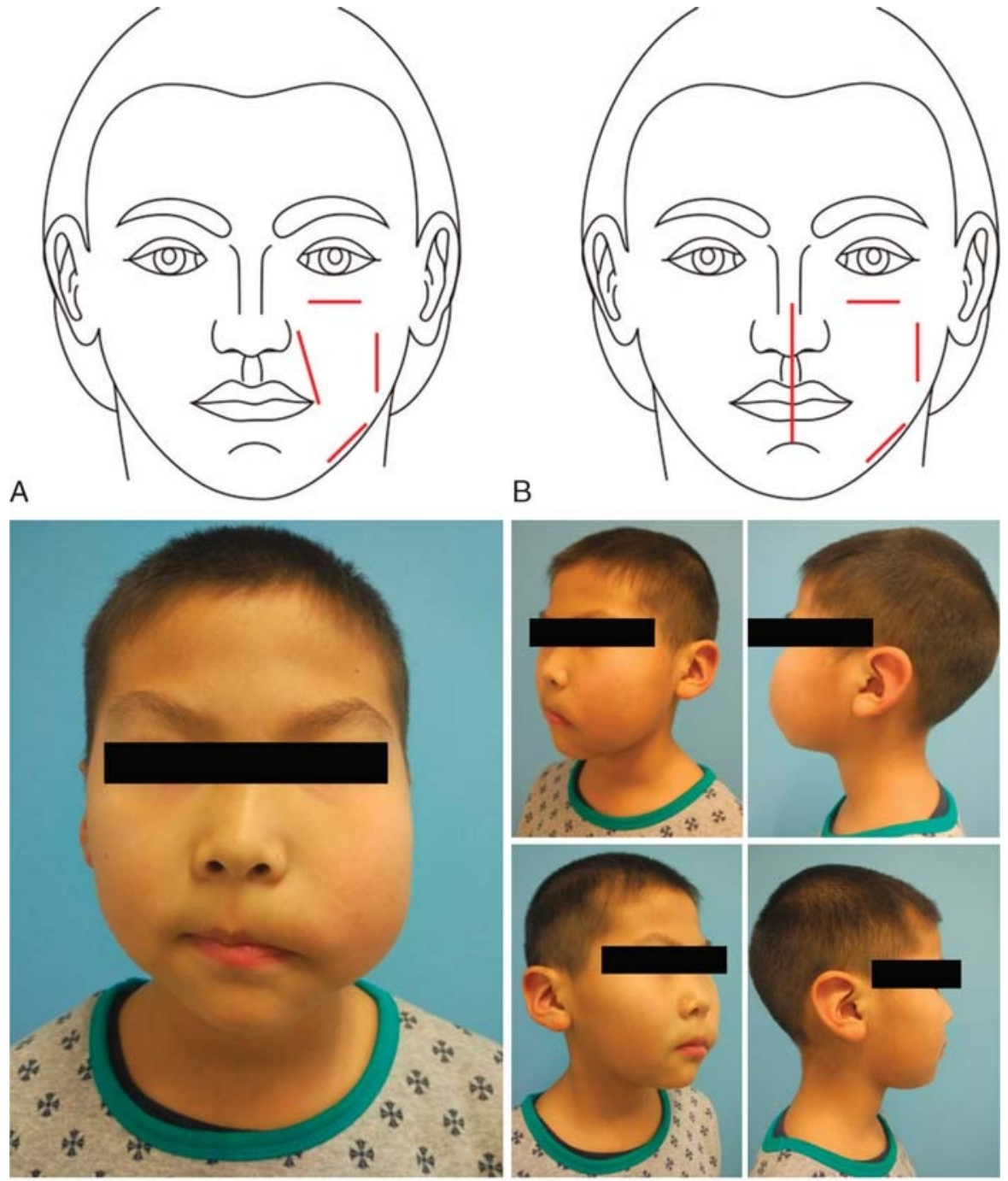

C

FIGURE 1. The schematic diagram of the 4 boundaries of the patient's left cheek enlargement when he was born ( $A$ ) and when presented to us (B), showing the progress of CILF and photos before surgery (C).

(Fig. 2C). Thus, an admitting diagnosis of subcutaneous tissue accumulation of the left maxillofacial region, lipomatosis probability was made.

The patient underwent a surgical treatment of subcutaneous lipectomy of the left maxillofacial lipomatosis on December 13, 2016. During the operation, we saw some big fat granules under the patient's skin, and his buccal fat pad was very thick (Fig. 3A). The postoperative pathological analysis reported the mass as mature fat tissue without any capsule (Fig. 3B). Therefore, we made the final diagnosis as subcutaneous lipomatosis of the left maxillofacial region comprehensively, and CILF was the most possible cause.

The patient and his family gave their informed consent for the treatment and inclusion in this study, after having been provided with all the necessary information. His outward appearance had certainly improved after the surgical treatment, and the postoperative MRI examination showed the same result (Fig. 3C). During a 6-month follow-up, there were no signs of disease recurrence or metastasis. A long-term follow-up will be done, to get more information about this rare disease.

\section{DISCUSSION}

\section{CILF and Differential Diagnosis}

Congenital infiltrating lipomatosis of the face is also called facial infiltrating lipomatosis. It is a congenital, nonhereditary disease, which was first described by Slavin et $\mathrm{al}^{5}$ in 1983 . Congenital infiltrating lipomatosis of the face is a very rare disorder, which is characterized by a collection of lipocytes with ill-defined borders that infiltrates surrounding muscles and soft tissues. Patients are presented with facial asymmetry at birth that evolves as the patient grows.

The etiology of CILF remains unknown. Originally, Donati et $\mathrm{al}^{6}$ considered the relationship between CILF and cytomegalovirus infection, and they reported such a case. Among the subsequent reports, only 1 case fitted this hypothesis, with anticytomegalovirus IgG positive and IgM negative. ${ }^{7}$ Couto et $\mathrm{al}^{8}$ proved that neovascularization does not play a potential role in the pathogenesis of CILF. Capra et $\mathrm{al}^{9}$ reported a deletion of chromosome 1q24.3q31.1 in a girl with pituitary deficiency and CILF. The current pathogenic theory was a somatic mutation 




A
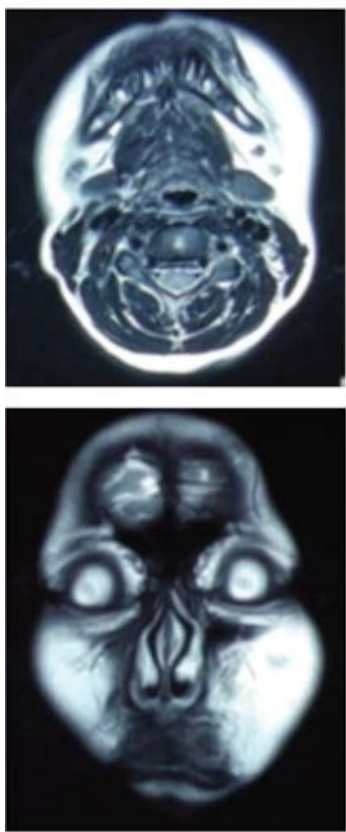

$\bar{C}$

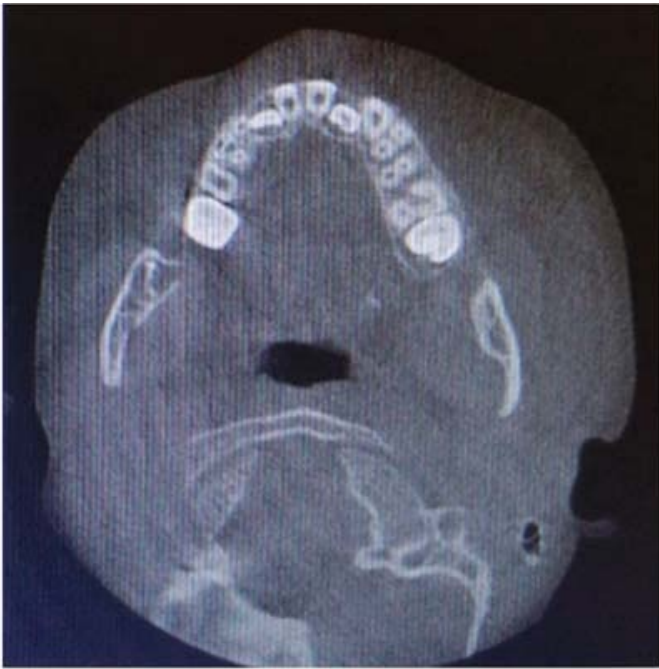

B
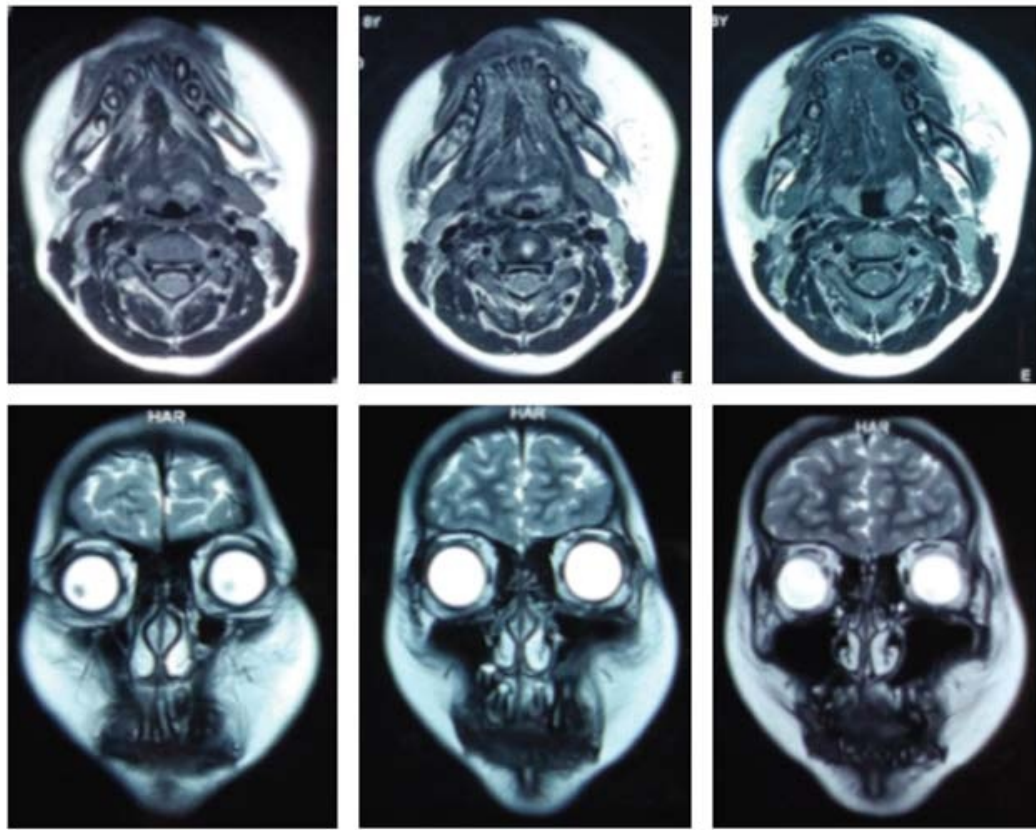

FIGURE 2. The preoperative image examinations of the patient, including the 3-dimension reconstruction of the CT scan of the skull, with an arrow pointing the abnormal big left upper canine (A), the CT scan of the teeth (B), and the MRI examination (C).

in the PIK3CA gene in the affected tissues, ${ }^{10}$ which is also detected in cancers and affected tissues from other nonheritable and overgrowth disorders. PIK3, encoded by PIK3CA, plays a crucial role in regulating cell proliferation, adhesion, survival, and motility. External environmental conditions, including irradiation, trauma, and degenerative processes with fatty transformation, could trigger and accelerate the lipomatous change.

Our diagnosis of CILF was based on the patient's medical history, clinical manifestations, and imaging features. The ill-defined fatty tissue could be detected by ultrasound, CT scan, and MRI, with infiltration into surrounding tissues, and no abnormal vascularity could be detected inside the lesions.

Histopathological analysis of the excised specimens could show the diffuse, nonencapsulated mature adipocytes variably infiltrated into submucosa, dermis, skeletal muscle, parotid, and minor salivary glands, with an increased number of small vessels and nerves. Neither lipoblasts nor signs of malignancy could be found. However, in our case, we did not resect any tissues except for adipose mass. Thus, our pathological reports only showed a mature fat tissue.

The differential diagnoses included encephalocraniocutaneous lipomatosis and Proteus syndrome. Encephalocraniocutaneous lipomatosis is characterized by lipomas of the scalp and central nervous system, as well as focal alopecia. ${ }^{10}$ Proteus syndrome is characterized by vascular malformations, lipomas, hyperpigmentation, and several types of nevi. Cutaneous lesions of Proteus syndrome tend to appear over time, the diagnosis may be delayed until late infancy, childhood, or even adulthood. ${ }^{11}$ According to the clinicopathological manifestations in our case, both of these 2 syndromes were eliminated. Moreover, other diseases, such as hemangioma and lymphangioma, were easily obsoleted by postoperative pathological diagnosis. 

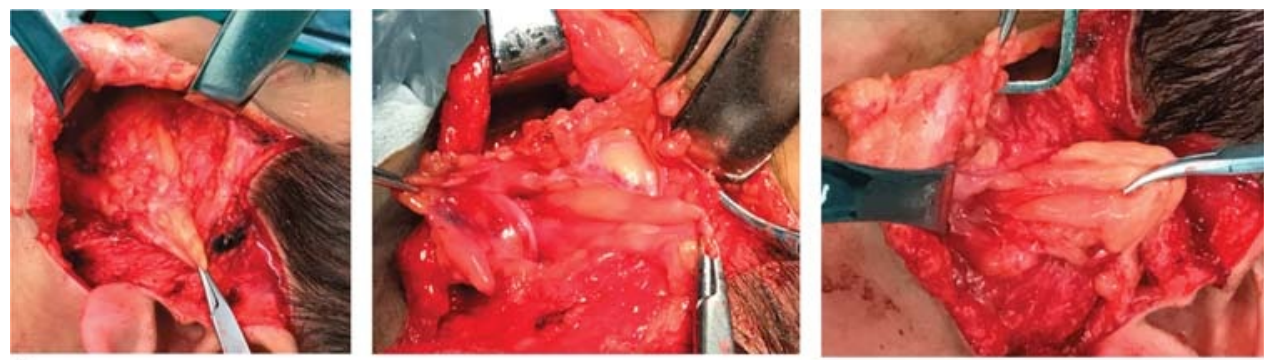

A

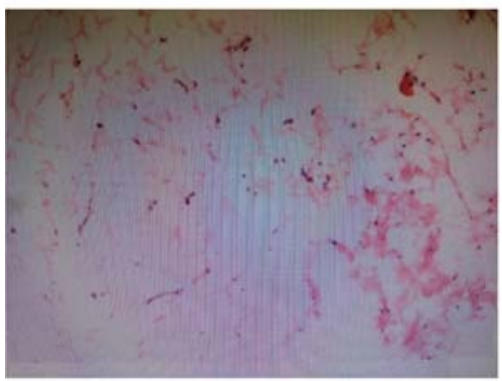

B

Preoperative


C
Postoperative


FIGURE 3. The intraoperative and postoperative findings: big fat granules under the skin and thick buccal fat pad (A); the pathological analysis showed a mature fat tissue (B); preoperative and postoperative photos and MRI examination results showed an obviously improved outward appearance as well as a more symmetrical face (C). 
TABLE 1. Case Reports of CILF

\begin{tabular}{|c|c|c|c|c|c|c|c|c|c|}
\hline Case & Author and Year & Sex & $\begin{array}{c}\text { Age at } \\
\text { First Clinic }\end{array}$ & Site & $\begin{array}{l}\text { Hypertrophy } \\
\text { of Bones }\end{array}$ & $\begin{array}{l}\text { Macrodontism } \\
\text { and Early Eruption } \\
\text { Of Deciduous And } \\
\text { Permanent Teeth On } \\
\text { The Affected Side }\end{array}$ & $\begin{array}{c}\text { Muscle } \\
\text { Involved }\end{array}$ & Surgery & Recurrence \\
\hline 1 & Slavin et al (1983) & M & 2 & $\mathrm{R}$ & $\mathrm{N}$ & $\mathrm{N}$ & $\mathrm{Y}$ & $\mathrm{Y}$ & $\mathrm{Y}$ \\
\hline 2 & & $\mathrm{~F}$ & 9 & $\mathrm{R}$ & Y: Zyg & $\mathrm{N}$ & $\mathrm{Y}$ & $\mathrm{Y}$ & $\mathrm{N}$ \\
\hline 3 & & $\mathrm{~F}$ & 2 & $\mathrm{R}$ & $\mathrm{N}$ & $\mathrm{N}$ & $\mathrm{N}$ & $\mathrm{Y}$ & $\mathrm{Y}$ \\
\hline 4 & DeRosa et al (1987) & M & 53 & $\mathrm{~L}$ & Y: Zyg, Max & $\mathrm{N}$ & $\mathrm{N}$ & $\mathrm{Y}$ & $\mathrm{Y}$ \\
\hline 5 & & $\mathrm{~F}$ & 9 & $\mathrm{~L}$ & Y: Max & $\mathrm{N}$ & $\mathrm{N}$ & $\mathrm{Y}$ & $\mathrm{Y}$ \\
\hline 6 & & $\mathrm{~F}$ & 23 & $\mathrm{R}$ & Y: Man & $\mathrm{N}$ & $\mathrm{N}$ & $\mathrm{Y}$ & $\mathrm{Y}$ \\
\hline 7 & $\begin{array}{l}\text { Van Wingerden et al } \\
\text { (1988) }\end{array}$ & M & 1.5 & $\mathrm{R}$ & $\mathrm{N}$ & $\mathrm{N}$ & $\mathrm{N}$ & $\mathrm{Y}$ & $\mathrm{N}$ \\
\hline 8 & $\begin{array}{l}\text { MacMillan et al } \\
\text { (1990) }\end{array}$ & $\mathrm{F}$ & 36 & $\mathrm{~L}$ & Y: Zyg, Max & $\mathrm{N}$ & $\mathrm{N}$ & $\mathrm{Y}$ & $\mathrm{Y}$ \\
\hline 9 & Donati et al (1990) & M & - & $\mathrm{L}$ & $\mathrm{Y}$ & $\mathrm{N}$ & $\mathrm{N}$ & $\mathrm{Y}$ & $\mathrm{N}$ \\
\hline 10 & Bataineh et al (1996) & $\mathrm{F}$ & 15 & $\mathrm{~L}$ & $\mathrm{~N}$ & $\mathrm{~N}$ & $\mathrm{~N}$ & $\mathrm{Y}$ & $\mathrm{N}$ \\
\hline 11 & Kang et al (1998) & M & 25 & $\mathrm{R}$ & Y: Zyg, Max & $\mathrm{N}$ & $\mathrm{N}$ & $\mathrm{Y}$ & $\mathrm{Y}$ \\
\hline 12 & $\begin{array}{l}\text { Bouletreau et al } \\
\quad(2000)\end{array}$ & $\mathrm{F}$ & 22 & $\mathrm{~L}$ & Y: Max, Man & Y & Y & Y & Y \\
\hline 13 & Unal et al (2000) & M & 2 & $\mathrm{~L}$ & $\mathrm{~N}$ & $\mathrm{~N}$ & $\mathrm{Y}$ & $\mathrm{Y}$ & $\mathrm{Y}$ \\
\hline 14 & & $\mathrm{~F}$ & 0.2 & $\mathrm{~L}$ & $\mathrm{~N}$ & $\mathrm{~N}$ & $\mathrm{~N}$ & $\mathrm{~N}$ & - \\
\hline 15 & & $\mathrm{~F}$ & 1.5 & $\mathrm{R}$ & $\mathrm{N}$ & $\mathrm{N}$ & $\mathrm{N}$ & $\mathrm{Y}$ & $\mathrm{Y}$ \\
\hline $16-28$ & Padwa et al (2001) & $\mathrm{M}=8 \mathrm{~F}=5$ & 12.4 & - & Y: Zyg, Max, Man & $\mathrm{Y}$ & $\mathrm{N}$ & $\mathrm{Y}$ & $\mathrm{Y}$ \\
\hline 29 & Aydíngöz et al (2002) & M & 0.25 & $\mathrm{~L}$ & $\mathrm{~N}$ & $\mathrm{~N}$ & $\mathrm{~N}$ & $\mathrm{~N}$ & - \\
\hline 30 & Chen et al (2002) & $\mathrm{F}$ & - & $\mathrm{L}$ & $\mathrm{Y}$ & $\mathrm{N}$ & $\mathrm{N}$ & Y & $\mathrm{Y}$ \\
\hline 31 & Unal et al (2002) & $\mathrm{F}$ & 2 & $\mathrm{~L}$ & $\mathrm{~N}$ & $\mathrm{~N}$ & $\mathrm{~N}$ & $\mathrm{Y}$ & $\mathrm{N}$ \\
\hline 32 & Malik et al (2004) & M & 22 & $\mathrm{R}$ & Y: Zyg, Max, Man & $\mathrm{Y}$ & $\mathrm{Y}$ & $\mathrm{Y}$ & $\mathrm{Y}$ \\
\hline $33-36$ & Haloi et al (2006) & - & - & - & $\mathrm{N}$ & $\mathrm{N}$ & $\mathrm{N}$ & $\mathrm{N}$ & - \\
\hline 37 & $\begin{array}{l}\text { Rajeswaran et al } \\
\text { (2008) }\end{array}$ & $\mathrm{F}$ & 11 & $\mathrm{R}$ & Y: Zyg, Max & $\mathrm{N}$ & $\mathrm{Y}$ & $\mathrm{Y}$ & - \\
\hline 38 & $\begin{array}{l}\text { Pires Fraga et al } \\
\text { (2008) }\end{array}$ & M & 2 & $\mathrm{~L}$ & $\mathrm{~N}$ & $\mathrm{~N}$ & $\mathrm{Y}$ & $\mathrm{Y}$ & $\mathrm{Y}$ \\
\hline 39 & Alkan et al (2009) & M & 1.5 & $\mathrm{~L}$ & $\mathrm{~N}$ & $\mathrm{Y}$ & $\mathrm{Y}$ & $\mathrm{Y}$ & $\mathrm{N}$ \\
\hline 40 & $\begin{array}{l}\text { Maruyama et al } \\
(2010)\end{array}$ & M & 4 & $\mathrm{R}$ & $\mathrm{N}$ & $\mathrm{N}$ & $\mathrm{N}$ & $\mathrm{N}$ & - \\
\hline 41 & Kim et al (2010) & $\mathrm{F}$ & 3.5 & $\mathrm{~L}$ & Y: Man & $\mathrm{N}$ & $\mathrm{Y}$ & $\mathrm{Y}$ & $\mathrm{Y}$ \\
\hline 42 & Kamal et al (2010) & $\mathrm{F}$ & 18 & $\mathrm{~L}$ & Y: Zyg & $\mathrm{N}$ & $\mathrm{N}$ & $\mathrm{Y}$ & $\mathrm{Y}$ \\
\hline 43 & & M & 2 & $\mathrm{~L}$ & Y: Max & $\mathrm{N}$ & $\mathrm{Y}$ & $\mathrm{N}$ & - \\
\hline 44 & Singh et al (2011) & $\mathrm{F}$ & 27 & $\mathrm{~L}$ & Y: Zyg & $\mathrm{N}$ & $\mathrm{N}$ & $\mathrm{Y}$ & $\mathrm{Y}$ \\
\hline 45 & Balaji et al (2012) & M & 3 & $\mathrm{~L}$ & Y: Zyg, Max, Man & $\mathrm{N}$ & $\mathrm{Y}$ & $\mathrm{Y}$ & $\mathrm{Y}$ \\
\hline 46 & Keramidas et al (2012) & M & 49 & $\mathrm{R}$ & $\mathrm{Y}$ & $\mathrm{N}$ & $\mathrm{Y}$ & $\mathrm{Y}$ & $\mathrm{Y}$ \\
\hline 47 & $\begin{array}{l}\text { Mahadevappa et al } \\
\text { (2012) }\end{array}$ & M & 0.75 & $\mathrm{R}$ & $\mathrm{N}$ & Y & $\mathrm{Y}$ & Y & $\mathrm{N}$ \\
\hline 48 & Talamanca et al (2012) & M & 0.5 & $\mathrm{~L}$ & Y: Zyg, Max & $\mathrm{N}$ & $\mathrm{Y}$ & $\mathrm{Y}$ & - \\
\hline 49 & Sahai et al (2013) & $\mathrm{F}$ & 54 & $\mathrm{R}$ & Y: Zyg, Max & $\mathrm{N}$ & $\mathrm{Y}$ & $\mathrm{Y}$ & $\mathrm{Y}$ \\
\hline 50 & Capra et al (2013) & $\mathrm{F}$ & - & $\mathrm{R}$ & Y & $\mathrm{N}$ & $\mathrm{Y}$ & $\mathrm{N}$ & - \\
\hline 51 & Tracy et al (2013) & $\mathrm{F}$ & 15 & $\mathrm{~L}$ & Y: Zyg & $\mathrm{N}$ & $\mathrm{Y}$ & $\mathrm{N}$ & - \\
\hline 52 & Sun et al (2013) & $\mathrm{F}$ & - & $\mathrm{L}$ & Y: Zyg, Max, Man & $\mathrm{Y}$ & $\mathrm{Y}$ & $\mathrm{N}$ & $\mathrm{Y}$ \\
\hline 53 & & $\mathrm{~F}$ & 8 & $\mathrm{R}$ & Y: Zyg, Max & $\mathrm{Y}$ & $\mathrm{Y}$ & $\mathrm{Y}$ & $\mathrm{Y}$ \\
\hline 54 & & $\mathrm{~F}$ & 16 & $\mathrm{~L}$ & Y: Zyg, Max & $\mathrm{Y}$ & $\mathrm{Y}$ & $\mathrm{Y}$ & $\mathrm{Y}$ \\
\hline 55 & & $\mathrm{~F}$ & 23 & $\mathrm{~L}$ & Y: Zyg, Max, Man & $\mathrm{N}$ & $\mathrm{Y}$ & $\mathrm{Y}$ & $\mathrm{Y}$ \\
\hline 56 & D'Souza et al (2014) & $\mathrm{F}$ & 17 & $\mathrm{~L}$ & Y: Zyg & $\mathrm{N}$ & $\mathrm{Y}$ & $\mathrm{Y}$ & $\mathrm{Y}$ \\
\hline 57 & $\begin{array}{l}\text { Santana-Ramirez et al } \\
\text { (2014) }\end{array}$ & M & 0.4 & $\mathrm{~L}$ & $\mathrm{~N}$ & $\mathrm{~N}$ & $\mathrm{Y}$ & $\mathrm{N}$ & - \\
\hline
\end{tabular}




\begin{tabular}{|c|c|c|c|c|c|c|c|c|c|}
\hline Case & Author and Year & Sex & $\begin{array}{c}\text { Age at } \\
\text { First Clinic }\end{array}$ & Site & $\begin{array}{c}\text { Hypertrophy } \\
\text { of Bones }\end{array}$ & $\begin{array}{l}\text { Macrodontism } \\
\text { and Early Eruption } \\
\text { Of Deciduous And } \\
\text { Permanent Teeth On } \\
\text { The Affected Side }\end{array}$ & $\begin{array}{c}\text { Muscle } \\
\text { Involved }\end{array}$ & Surgery & Recurrence \\
\hline 58 & Shenoy et al (2015) & M & 6 & $\mathrm{~L}$ & Y: Max & $\mathrm{N}$ & Y & $\mathrm{N}$ & - \\
\hline 59 & This case & M & 8 & $\mathrm{~L}$ & $\mathrm{Y}$ & $\mathrm{N}$ & $\mathrm{N}$ & $\mathrm{Y}$ & \\
\hline Total & & $\begin{array}{c}\mathbf{M}=27 \\
\mathbf{F}=\mathbf{2 8}\end{array}$ & $\begin{array}{c}\text { Average } \\
11.9\end{array}$ & $\begin{array}{l}\mathbf{R}=\mathbf{1 5} \\
\mathbf{L}=\mathbf{2 7}\end{array}$ & $Y=69.49 \%$ & $Y=33.90 \%$ & $Y=40.68 \%$ & $Y=77.97 \%$ & $Y=62.71 \%$ \\
\hline
\end{tabular}

F indicates female; L, left; M, male; Man, mandible; Max, maxillary; R, right; Y, yes; N, no; Zyg, zygoma.

However, the term lipomatosis implies multiple lipomas, which are not a component of CILF. Thus, adiposis may be a better word to describe the proliferation of adipose cells and the accumulation of mature fat tissue. Because CILF is very rare, more data and discussion are needed to give a more accurate description about the disease.

\section{Review of Literatures}

To investigate more about CILF, the PubMed, Embase, and Science Citation Index databases were systematically searched until January, 2017. The key words used were "lipomatosis," "face/facial," "infiltrating," and "congenital." The citation lists associated with all of the studies retrieved were used to identify other potentially relevant publications. The reference lists were also checked, including case and review publications. The search results were then screened according to the following inclusion criteria: (1) any form of publications focused on facial asymmetry at birth, with or without cutaneous, subcutaneous, skeletal, sarcous, and neurological clinical manifestations; and (2) presentation of sufficient data, including clinical characteristics and histopathological detection. Studies were excluded if they met the following criteria: (1) were not published in English; and (2) duplicated data from the same sample of patients.

The systematic search yielded a total of 59 patients including the 1 reported in this article. ${ }^{1,2,4-7,9,12-36}$ The male-to-female ratio was 1:1.037, with no sex differences. All of those patients were presented with facial soft tissue mass, which was nonpulsatile, noncompressible, ill-defined, and facial asymmetry (100\%). Among them, 42 cases described the site of the facial mass, $64 \%$ of which were on the left. The lesions could range from infraorbital rim, along the inferior mandibular border and lateral border of the nose, to the lower lip, even the ear and neck ( 2 cases, $3 \%$ ) of the affected side (Table 1 ).

Forty-one cases (69\%) showed ipsilateral hypertrophy of the underlying facial skeleton, among which 24 cases (67\%) of zygoma, 23 cases $(64 \%)$ of maxilla, and 11 cases $(31 \%)$ of mandibule were involved. Bony asymmetry seemed to increase with age. Adipose tissue infiltrated into surrounding tissues, which caused muscles (24 cases, $41 \%$; such as masseters, pterygoid plate, and temporalis muscles) and parotid glands involvement (22 cases, 37\%). Oral malformation was also described. Macroglossia was involved in 19 cases (32\%). Nineteen cases $(32 \%)$ exhibited early eruption of deciduous and permanent teeth on the affected side. Thirteen cases $(22 \%)$ were presented with teeth missing, and 11 cases (19\%) exhibited macrodontism. Intracranial abnormality was reported in 10 cases (17\%), which presented as unilateral hemimegalencephaly, which showed hypertrophy of cerebral hemisphere, unilateral diffuse pachygyria, thickening of gray matter, enlargement of lateral hemi-ventricle, and 2 high-signal intensities in the white matter. Pigmented nevi was observed in 4 cases (7\%) (Table 1).

There were no abnormal results of ophthalmological and buccal neurological examinations, and no vascular problems reported. Since the hemihypertrophy alongside the oral cavity, the oropharynx, the floor of the mouth and the tongue, obstructive sleep apnea, and hypoxia were observed by polysomnogram monitoring in some cases.

Among all the 58 cases in previous literatures, 38 patients $(64 \%)$ got at least 1 plastic surgery, whereas the recurrence rate was $79 \%$ (Table 1). Only a very few cases had a good cosmetic result after a single surgery, whereas others required multiple operations. On an average, 1.95 operations had been performed for each recurrent case. Fortunately, there was no case of distal metastasis reported before.

\section{Treatments of CILF}

The treatment modalities available were liposuction and excision. Although the tumor is benign, the rate of recurrence is very high after surgical excisions. Multiple surgeries are needed for cosmetic reasons. Debulking surgeries were usually performed through a rhytidectomy incision, during which doctors needed to try to preserve the facial nerve. Sometimes, osseous reduction operations of the zygoma, maxilla, and mandibule were performed if necessary.

In 2013, Tracy et $\mathrm{al}^{35}$ reported a new therapeutic protocol involving surgical resection and targeted chemotherapy. Doctors analyzed the surgical specimen and found the expression of c-kit (CD117) and platelet derived growth factor receptor. Imatinib and celecoxib were prescribed as personalized targeted chemotherapy, which demonstrated improved facial symmetry without evidence of disease progression. Combining surgical and medical intervention may allow for a synergistic approach to controlling this rare disease, which could be the future treatment paradigm.

Because the PIK3CA gene mutation is the promising pathogenic theory, PI3K inhibitors, which are currently used in clinical trials for patients with cancer, may play a therapeutic role in patients with CILF. ${ }^{10}$ Even if the disorder could not be cured, PI3K inhibitor might prevent progression or recurrence of CILF.

However, as an extremely rare disease, there were not so many reports about CILF. Therefore, a proper surgical treatment was always operated according to the surgeon's experiences. Moreover, the adjuvant treatment was still in research. Besides, facial appearance is very important to everybody. Thus, it is significant to give a psychological guidance along with the process of multiple surgical treatments. Comprehensive treatment is crucial for such a disease, and more cases are needed to conclude a better therapy.

\section{CONCLUSIONS}

Congenital infiltrating lipomatosis of the face is a very rare disease. In this article, we reported 1 new case in our hospital, and reviewed the related literatures including 58 cases all over the world. Although CILF has a benign behavior, the gradual continuing progress and high recurrence rate asked us to learn more about it. Because facial appearance is very important, the efficacy of surgical treatment, 
adjuvant therapy, and psychological intervention are significant to both patients and doctors. Thus, a proper collection and analysis of the reports of such a disease are very important to help us learn more do more for those patients.

\section{REFERENCES}

1. De RG, Cozzolino A, Guarino M, et al. Congenital infiltrating lipomatosis of the face: report of cases and review of the literature. J Oral Maxillofac Surg. 1987;45: 879-883.

2. Keramidas T, Lagogiannis G, Vlachou V, et al. Congenital infiltrating lipomatosis of the face with associated involvement of the TMJ structures. Case report and review of the literature. J Craniomaxillofac Surg. 2012;40:750-756.

3. Flores-Sarnat L. Congenital infiltrating lipomatosis of the face: recognition and pathogenesis. Neuropediatrics. 2012;43:346.

4. Kamal D, Breton P, Bouletreau P. Congenital infiltrating lipomatosis of the face: report of three cases and review of the literature. J Craniomaxillofac Surg. 2010;38:610-614.

5. Slavin SA, Baker DC, McCarthy JG, et al. Congenital infiltrating lipomatosis of the face: clinicopathologic evaluation and treatment. Plast Reconstr Surg. 1983; 72:158-164.

6. Donati L, Candiani P, Grappolini S, et al. Congenital infiltrating lipomatosis of the face related to cytomegalovirus infection. Br J Plast Surg. 1990;43:124-126.

7. Aydíngöz U, Emir S, Karlí-Oğuz K, et al. Congenital infiltrating lipomatosis of the face with ipsilateral hemimegalencephaly. Pediatr Radiol. 2002;32:106-109.

8. Couto RA, Mulliken JB, Padwa BL, et al. Facial infiltrating lipomatosis: expression of angiogenic and vasculogenic factors. J Craniofac Surg. 2011;22: 2405-2408.

9. Capra V, Severino M, Rossi A, et al. Pituitary deficiency and congenital infiltrating lipomatosis of the face in a girl with deletion of chromosome 1q24.3q31.1. Am J Med Genet A. 2014;164A:495-499.

10. Maclellan RA, Luks VL, Vivero MP, et al. PIK3CA activating mutations in facial infiltrating lipomatosis. Plast Reconstr Surg. 2014;133:12e-19e.

11. Sant'Anna GD, Saffer M, Mauri M. Encephalocraniocutaneous lipomatosis with otolaryngologic manifestations: a rare neurocutaneous syndrome. Int J Pediatr Otorhinolaryngol. 1999;49:231-235.

12. Shenoy AR, Nair KK, Lingappa A, et al. Congenital infiltrating lipomatosis of face: case report and review of literature. J Indian Soc Pedod Prev Dent. 2015;33:156-160.

13. Macmillan AR, Oliver AJ, Reade PC, et al. Regional macrodontia and regional bony enlargement associated with congenital infiltrating lipomatosis of the face presenting as unilateral facial hyperplasia. Brief review and case report. Int J Oral Maxillofac Surg. 1990;19:283-286.

14. Bouletreau P, Breton P, Freidel M. Congenital infiltrating lipomatosis of the face: case report. J Oral Maxillofac Surg. 2000;58:807-810.

15. Kang N, Ross D, Harrison D. Unilateral hypertrophy of the face associated with infiltrating lipomatosis. J Oral Maxillofac Surg. 1998;56:885-887.

16. Bataineh AB, Mansour MJ, Abalkhail A. Oral infiltrating lipomas. Br J Oral Maxillofac Surg. 1996;34:520-523.
17. Padwa B, Mulliken J. Facial infiltrating lipomatosis. Plast Reconstr Surg. 2001; 108:1544-1554.

18. Unal O, Cirak B, Bekerecioglu M, et al. Congenital infiltrating lipomatosis of the face with cerebral abnormalities. Eur Radiol. 2000;10:1610-1613.

19. Haloi AK, Ditchfield M, Penington A, et al. Facial infiltrative lipomatosis. Pediatr Radiol. 2006;36:1159-1162.

20. Malik A, Jagmohan P, Thukral BB, et al. Congenital infiltrating lipomatosis of the face and neck. Acta Radiol. 2004;45:556-560.

21. Unal S, Demirkan F, Arslan E, et al. Infiltrating lipomatosis of the face: a case report and review of the literature. J Oral Maxillofac Surg. 2003;61:1098-1101.

22. Chen CM, Lo LJ, Wong HF. Congenital infiltrating lipomatosis of the face: case report and literature review. Chang Gung Med J. 2002;25:194-200.

23. Pires Fraga MF, Mello D, Jorge D, et al. Congenital infiltrating lipomatosis. J Plast Reconstr Aesthet Surg. 2009;62:e561-e564.

24. Alkan O, Yildirim T, Seyhan T, et al. Congenital infiltrating lipomatosis of the face with hemimegalencephaly. Neuropediatrics. 2009;40:141-143.

25. Rajeswaran R, Murthy J, Chandrasekharan A, et al. Case report: congenital infiltrating lipomatosis of face. Indian J Radiol Imaging. 2008;18:306-309.

26. Maruyama K, Okumura A, Negoro T, et al. Congenital infiltrating lipomatosis of the face with ipsilateral hemimegalencephaly, band heterotopia, and hypertrophy of brainstem and cerebellum. Neuropediatrics. 2010;41:147-150.

27. Kim JE, Gottschall JA, Bachman RP, et al. Facial infiltrating lipomatosis: physical, radiological, and histopathological findings. Arch Otolaryngol Head Neck Surg. 2010;136:301-303.

28. Balaji SM. Congenital diffuse infiltrating facial lipomatosis. Ann Maxillofac Surg. 2012;2:190-196.

29. Singh K, Sen P, Musgrove BT, et al. Facial infiltrating lipomatosis: a case report and review of literature. Int J Surg Case Rep. 2011;2:201-205.

30. Sahai S, Rajan S, Singh N, et al. Congenital infiltrating lipomatosis of the face with exophytic temporomandibular joint ankylosis: a case report and review of the literature. Dentomaxillofac Radiol. 2013;42:243-251.

31. Talamanca LF, Verdolotti T, Colafati GS, et al. Hemimegalencephaly associated with congenital infiltrating lipomatosis of the face: a case report. Neuropediatrics. 2012;43:349-352.

32. Mahadevappa A, Raghavan VH, Ravishankar S, et al. Congenital infiltrating lipomatosis of the face: a case report. J Oral Maxillofac Surg. 2000;58: $807-810$

33. Santana-Ramirez A, Farias-Serratos F, Sanchez-Corona J, et al. Hemimegalencephaly with facial congenital infiltrating lipomatosis in a child. Iran J Public Health. 2014;43:1702-1709.

34. D'Souza D, Babu GS, Shetty SR, et al. Congenital infiltrating lipomatosis of the face: a case report with review of literature. Indian Dermatol Online J. 2014;5: 303-305.

35. Tracy JC, Klement GL, Scott AR. Interdisciplinary management of congenital infiltrating lipomatosis. Int J Pediatr Otorhinolaryngol. 2013;77:2071-2074.

36. Sun L, Sun Z, Zhu J, et al. Tooth abnormalities in congenital infiltrating lipomatosis of the face. Oral Surg Oral Med Oral Pathol Oral Radiol. 2013, 115:e52-e62. 